\title{
Industrial and domestic energy consumption in Nellore villages
}

\author{
SIDDHARTHA BHATT M \\ Central Power Research Institute, Bangalore-560012 \\ MS received 9 July 1982; revised 15 July 1984
}

\begin{abstract}
The paper deals with the determination of energy consumption for work like brickburning, pottery-making, rice milling, flour milling, edible oil extraction and hand-digging of borewells; and for domestic tasks like cooking, water heating, lighting, etc. The energy consumption is evaluated by physically measuring the fuel and labour inputs and monitoring the area for a month.
\end{abstract}

Keywords. Rural energy; rural industries; rural households.

\section{Introduction}

Energy studies were conducted in a few villages of the Nellore district of Andhra Pradesh in South India for 30 days during April-May 1982. The main considerations for choosing this locality were that (a) it is intermediate between the extremely rainy regions of the Western Ghats and the dry regions around Bangalore, (b) it is not significantly affected by urbanisation.

The studies were conducted during Aptil-May because most rural industries are seasonal. Brick and pot making industries function only during February-May when there are very few chances of rainfall. The region receives rainfall $(\approx 400 \mathrm{~mm} /$ year $)$ from the South-East monsoons during August-October, while there is bright sunshine the rest of the year. The common soils are of the sandy, loamy or black cotton type. The place is irrigated by the waters of the Pennar river during August-December.

\section{Experimental procedure}

\subsection{Industrial energy}

In potteries, non-commercial brick-burning and blacksmithy the fuel charge, prior to firing and the later additions, was weighed. The other inputs were actually measured during operation. As the measurements were taken at two places, the results could be cross verified. Surprisingly the values showed very little variation.

In commercial brick-making, the rice husk input was estimated in terms of the number of sacks. The other inputs were estimated from the owners' statements and cross-verified from other sources.

Accurate estimates of the operating times and other details of rice, flour and oil mills were obtained from several mills. 


\subsection{Domestic energy}

Six households who offered their co-operation were chosen for detailed study. About $25 \mathrm{~kg}$ of firewood was weighed in each house in the evening and the people were told to use firewood only from that lot for the whole of the next day. At the end of the test day (8p.m.) when all the cooking was over, the remaining wood was weighed and the consumption noted. As variables such as the kind of food cooked each day (requiring different cooking periods), etc, come into the picture, the consumption was monitored for a week. In spite of strict instructions, some households used twigs from outside the weighed lot but when specifically asked they admitted to doing so. Also, some households tried to give a higher value of firewood consumption by hiding a few logs, which was probably because of the impression that higher consumption denotes a higher level of living and also because a comparative statement was being prepared. Negative and positive corrections were applied for these two problems.

Monitoring of kerosene and electricity consumption and of human labour was straightforward and did not create any problems.

The following procedure was adopted for finding out the domestic energy consumption in the four villages.

The total number of cookstoves and bathwater heaters and the average number of hours of operation per day of each of these were determined from a survey of all the houses in all the villages. The firewood consumption/hour was determined for each typical stove and this was extrapolated to find out the firewood consumption.

The total household electrical loads and the number of hours of operation of each load were determined. Similarly, the survey also included finding out the number of kerosene lamps, the number of hours spent/household in drawing water, washing, taking care of cattle, etc.

\section{Assumptions in the energy calculations}

\subsection{Common energy scale}

The various energy inputs like human energy, fuel charge, electricity, etc, are measured on a common energy scale-kilocalories $(1 \mathrm{kcal}=4 \cdot 1868 \mathrm{~kJ})$ or kilowatt hours $(1 \mathrm{kwh}=3.6 \mathrm{MJ})$.

\subsection{Energy conversion chain}

Energy is assumed to flow through conversion chains starting with a resource and ending in the performance of useful tasks. In this paper, only that portion of the energy conversion chain which is significant for rural tasks is considered. With this in mind, two terms have been coined by the author.

3.2a Resource-end energy: It is the energy consumption measured prior to the performance of the task, eg, diesel for a tractor, food for cattle, electrical input to a pump measured at the load point, etc.

$3.2 b$ End-point energy or task-end energy: It is the ultimate useful energy derived from an energy source, eg, mechanical work done by a tractor, potential energy of water lifted by a pump, useful heat output of a stove, etc.

The resource-end energy and the task-end energy cannot be added to each other as 
the overall system efficiency has to be considered. Thus the resource-end energy for all tasks is added separately and so is the end-point energy.

For tasks discussed in this paper, the resource-end energy values are considered for calculations as they represent the real energy consumption of the system.

\subsection{System boundaries}

In the case of external energy sources like electricity, kerosene, diesel, etc, the resourceend energy is considered at the system boundaries, ie, at the time of its entry to the village. Thus electricity is considered as $\mathrm{kWh}$ at the load point and not at the generating point; diesel is considered as litres of diesel bought at the village and not at the refinery or as crude at the oil well. For example, if diesel is considered when bought at the refinery, the energy for its transport has also to be considered. Similarly if it is considered when bought as crude at an oil well, the energy for its transportation and for the refining process, etc, has to be considered.

\subsection{Energy inputs}

Either of the following two approaches are used to find the resource-end energy or the energy input:

(i) In cases where the resource-end energy cannot be found out directly, the value is determined from a back calculation based on the knowledge of the device power output (end-point energy per unit time), the period of operation and the device efficiency, eg, human or animal energy, etc.

(ii) In cases where the resource-end energy is in the form of fuel the energy input is directly computed based on consumption. Table 1 gives the energy values used for calculations. This table also gives the expansions for abbreviations of energy units used in the text and subsequent tables.

\section{5 "Free" and "exerted" energy inputs}

Sunshine, wind, flow of water, etc, in their natural forms are considered as "free" rural energies and their contributions are not portrayed in the calculations, while the contributions of "exerted" energies like animal power, diesel, agrowastes, etc, are considered. However, if free inputs are harnessed by solar collectors, wind mills, etc, then their contributions become valid and enter the calculations.

\subsection{Consistency}

The power input-output values, in spite of their wide variations are taken as constants in the calculation.

\subsection{Calorific values}

The following calorific values are experimentally established: $(\mathrm{kcal} / \mathrm{kg})$ : dung cakes-2095; rice-husk - 3000; hay-3500; toddy-palm leaves-3600; casuarina loppings (leaf + branch biomass)-3800; toddy-palm roots-4200; Prosopis julifiora (hardwood)4400; coal-6000; diesel-10,700; kerosene-10,900. 
Table 1. Energy values for calculations

\begin{tabular}{|c|c|c|c|c|}
\hline Device & $\begin{array}{c}\text { Power } \\
\text { output } \\
\text { (kW) }\end{array}$ & $\begin{array}{c}\text { Energy } \\
\text { unit }\end{array}$ & $\begin{array}{c}\text { Overall } \\
\text { efficiency } \\
\text { of device } \\
(\%)\end{array}$ & $\begin{array}{l}\text { Resource-end } \\
\text { energy }\end{array}$ \\
\hline Man & $0-08^{a, b}$ & $\mathrm{~m}-\mathrm{h}$ & $3^{f}$ & $2.3 \times 10^{3} \mathrm{kcal} / \mathrm{h}$ \\
\hline Bullock & $0.36^{c}$ & b-h & $5^{0}$ & $6.2 \times 10^{3} \mathrm{kcal} / \mathrm{h}$ \\
\hline Ploughing force & $0-80$ & p-h & 5 & $13.76 \times 10^{3} \mathrm{kcal} / \mathrm{h}$ \\
\hline Bullock cart & 0.72 & c-h & 5 & $12.38 \times 10^{3} \mathrm{kcal} / \mathrm{h}$ \\
\hline Eloctric pump & $(3.73)^{e}$ & $e-h$ & 30 & $18 \mathrm{kWh} / \mathrm{h}$ \\
\hline Tractor & $(26 \cdot 11)^{e}$ & tc-h & 18 & $51 / h^{j}$ \\
\hline Diesel pump & $(5.97)^{e}$ & d-h & 24 & $0.421 / h^{j}$ \\
\hline Truck & $(104 \cdot 4)^{e}$ & & & \\
\hline i) tonnes basis & & $\mathrm{t}-\mathrm{km}$ & $9^{h}$ & $(30)^{-1} 1 / \mathrm{t}-\mathrm{km}^{j}$ \\
\hline $\begin{array}{l}\text { ii) overall truck } \\
\text { basis }\end{array}$ & & tr-km & $9^{h}$ & $0.341 / \mathrm{tr}-\mathrm{km}^{j}$ \\
\hline Bus (human travel) & $(89.5)^{e}$ & $\mathbf{m}-\mathbf{k m}$ & $9^{h}$ & $(640)^{-1} 1 / \mathrm{m}-\mathrm{km}^{j}$ \\
\hline Solar energy & $\begin{array}{l}(74.84 \\
97.07) / \text { hectare }\end{array}$ & s-d & $1^{i}$ & $(4 \cdot 5-6 \cdot 8) \mathrm{kWh} / \mathrm{m}^{2} / \mathrm{day}^{*}$ \\
\hline
\end{tabular}

a Source: (Forbes 1958); ' source: (Wilson 1977); ' source: (Birch \& Rudzewski 1980); 'two bullocks and a man; " refers to shaft power output-a stage before the end-point energy stage, these are not considered as resource-end energy data and efficiencies are accurately known; $f$ source: (Revelle 1976); 'source: (Makhijani 1977); " source: (Pierce 1975); ${ }^{i}$ the overall efficiency of solar energy to biomass is $01 \%$ (Wise 1981 ) and the photosynthetic efficiency is $10 \%$ (Hogg 1971), the overall efficiency of solar energy in the present context is therefore $1 \%$; ' resource-end energy is given in terms of diesel consumed per hour, per tonne-km, truck-km and man-km, multiplying by the total distance travelled, the fuel consumption can be evaluated; " values during extreme conditions in regions around Nellore, source: (Mani 1981);

Abbreviations:

m-h: man-hour; b-h: bullock-hour; p-h: plough-hour; c-h: cart hour; e-h: electric-pump-hour; tc-h: tractorhour; d-h: diesel-pump-hour; t-km: tonne-kilometer; tr-km: truck-kilometer; m-km: man-kilometer; s-d: solar-day

\section{Energy for rural industries}

\subsection{Brick-burning (hand-moulded)}

Brick-burning is either commercial or non-commercial. In the former, $50 \times 10^{3}$ to 3 $\times 10^{5}$ bricks are fired in kiln sizes varying from $10 \times 8 \mathrm{~m}^{2}$ to $17 \times 17 \mathrm{~m}^{2}$ (ground area) and fuelled by rice-husk and small quantities of casuarina loppings. The bricks are sold in the market. Non-commercial kilns are fuelled by firewood or rice husk and are used to burn upto $50 \times 10^{3}$ bricks. These bricks are for the owners' personal use.

4.1a Commercial brick-burning: (i) Procedure for brick-making-The bricks are dried for at least 6 days after casting. Alternate layers of bricks and rice-husk are arranged to form a truncated pyramid after first constructing the kiln wall. The bottom-most and topmost layers of rice-husk are 0.75 and $0.35 \mathrm{~m}$ deep respectively. About six end to end holes, each of two brick height and one brick length are made. Into this are inserted casuarina loppings for initial firing of the kiln. These channels have no vents other than their open side for the escape of exhaust gases. The whole kiln is covered with a layer of mud. 
The firing is started in the evening. The burning time is 15 days and the cooling time is 10 days. Five to six days after the start of the burning operations, the mud covering of the kiln gets loosened and the bricks are exposed to the atmosphere, when some more mud is used to cover them. After 25 days the bricks are ready for use. Figure 1 depicts a typical commercial brick kiln used in Nellore.

(ii) Energy consumption for making 1 lakh bricks: The usual capacity of a rice-huskfired kiln is one lakh bricks per load. The kiln ground area is $14 \times 9.4 \mathrm{~m}^{2}$. The operations are conducted at a point where mud is available on the spot and rice-husk close by. The burnt bricks are transported over a distance of $16-18 \mathrm{~km}$.

The energy consumption is as follows: Fuel: rice-husk $-45,500 \mathrm{~kg}$, casuarina loppings - $200 \mathrm{~kg}$; preparation of field for drying of bricks, weeding and levelling - 160 man hours $(\mathrm{m}-\mathrm{h})$; preparation of mud for brick casting $-40 \mathrm{~m}-\mathrm{h}+0.5$ electric pump hours (e-h); casting of bricks - $100 \mathrm{~m}-\mathrm{h}$; transportation of bricks to the kiln-160 m-h; bringing bricks into the kiln and placing it in the kiln- $-800 \mathrm{~m}-\mathrm{h}$; setting up brick walls for the kiln- $80 \mathrm{~m}$-h; loading of casuarina loppings at the energy plantation, transportarion and unloading at the site $-25 \mathrm{~m}-\mathrm{h}+3$ cart hours (c-h); loading, transporting and unloading of rice husk $-65 \mathrm{c}-\mathrm{h}+130 \mathrm{~m}-\mathrm{h}$; arranging the fuel in the kiln- $400 \mathrm{~m}-\mathrm{h}$; transporting mud for first and second covering - $20 \mathrm{c}-\mathrm{h}$; initial covering of mud- $-160 \mathrm{~m}-\mathrm{h}$; covering with mud after 5-6 days-96 m-h; removal of bricks from kiln- $800 \mathrm{~m}-\mathrm{h}$; transportation in lorry through $12 \mathrm{~km}-480$ truck kilometer (tr-km). Table 2 gives the energy consumption in commercial brick burning.

4.1b Non-commercial brick burning: The popular size (capacity of kiln) for personal brick burning is 25,000 . If the locally available Prosopis juliflora hardwood is used as fuel, the resource-end energy is $33.16 \times 10^{6} \mathrm{kcal}$ and the end-point energy is 1.02 $\times 10^{6} \mathrm{kcal}$ for $25 \times 10^{3}$ bricks.

\subsection{Potteries}

4.2a Traditional kilning practice: Pots are burnt in traditional kilns which are built into the ground. Only one wall, $i e$, the front wall with the fuel feed opening is made of bricks. The ground itself acts as a wall (on the other side) which is semi-oval in shape. The pots

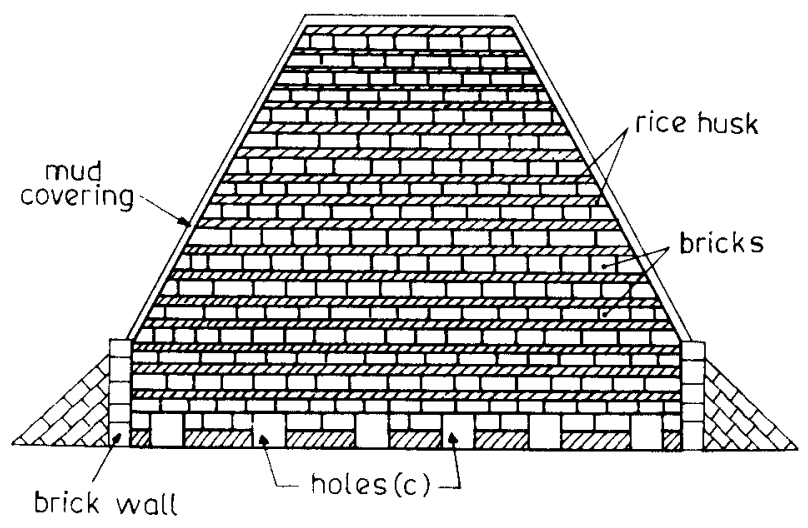

Figure 1. A commercial brick kiln 
Table 2. Energy consumption in brick-burning

\begin{tabular}{lcc}
\hline Energy & $\begin{array}{c}\text { Resource-end energy } \\
\left(\times 10^{3} \mathrm{kcal}\right)\end{array}$ & $\begin{array}{c}\text { End-point energy } \\
\left(\times 10^{3} \mathrm{kcal}\right)\end{array}$ \\
\hline Fuel & $137260 \cdot 0$ & 13726.0 \\
$0.5 \mathrm{e}-\mathrm{h}$ & 7.7 & $2 \cdot 3$ \\
$2950 \mathrm{~m}-\mathrm{h}$ & $6765 \cdot 3$ & $203 \cdot 0$ \\
$88 \mathrm{c}-\mathrm{h}$ & 1090.0 & $54 \cdot 5$ \\
$480 \mathrm{tr}-\mathrm{km}$ & 1712.0 & $154 \cdot 1$ \\
Total & 146835.0 & 14140.0 \\
\hline
\end{tabular}

- Assuming a kiln efficiency of $10 \%$

(placed inverted) are loaded into this kiln, one on top of the other. Parallel rows of pots and wood are placed. After all the pots and the fuel are in place, the kiln is closed at the top by a layer of mud with 10-15 vents for exhaust gases. The firing usually takes $6 \mathrm{hr}$ and the pots are removed after cooling by breaking open the top mud layer.

A variety of pot sizes, kiln sizes and fuels are in use and hence the energy consumption is evaluated for a medium-sized kiln burning medium-sized pots using the most common kilning fuel in the locality.

Such a kiln is shown in figure 2 and the pot size for which the energy consumption is evaluated is shown in the insert. The fuel used is primarily the toddy-palm root, and minor quantities of hay, toddy-palm leaves, rice husk and twigs of Prosopis juliflora. Figure 3 gives a horizontal cross-section of a conventional pottery kiln.

$4.2 b$ Energy consumption for making 200 pots: Usually in one firing of a medium kiln 200 pots (size as shown in figure 2) can be burnt and hence, for convenience this is selected as the number for energy estimation. In practice an assortment of pots are burnt.

The energy consumption is as follows: fuels: toddy-palm roots- $200 \mathrm{~kg}$; rice husk-

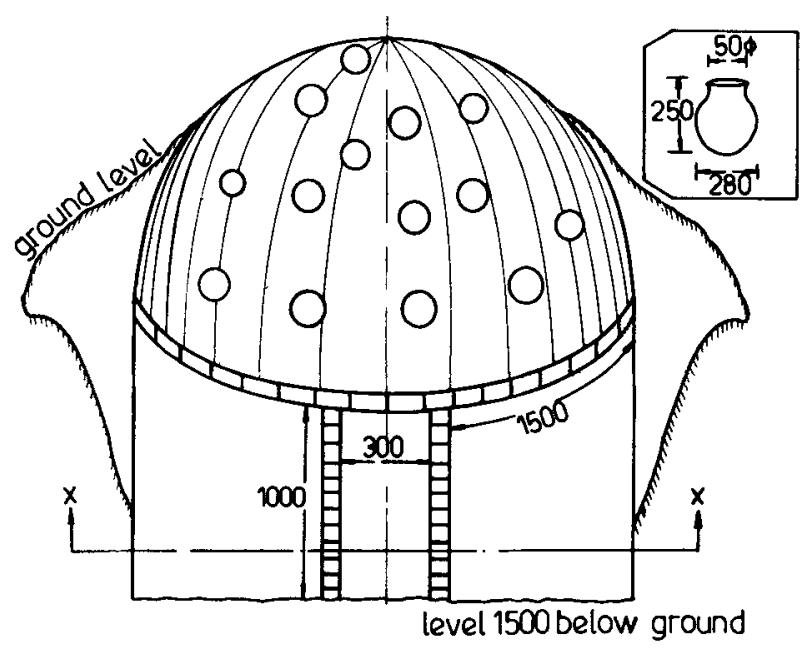

Figure 2. A conventional pottery kiln 


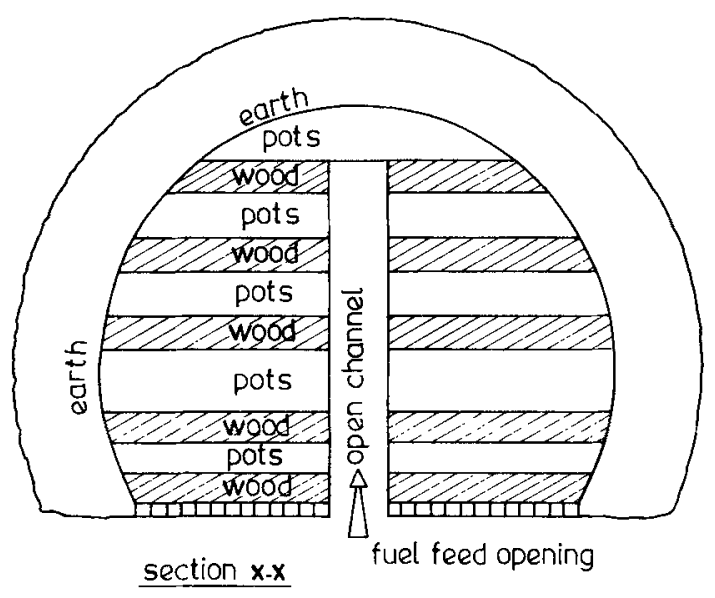

Figure 3. Horizontal cross-section of a conventional pottery kiln

$35 \mathrm{~kg}$; toddy-palm leaves- $12 \mathrm{~kg}$, transportation of mud to work site $-8 \mathrm{c}-\mathrm{h}+1 \mathrm{~m}-\mathrm{h}$; initial preparation of soil, moulding the pots on the wheel- $54 \mathrm{~m}-\mathrm{h}$; collecting and carrying of fuel to the work site $-5 \mathrm{~m}-\mathrm{h}$; bringing the pots from the house to the kiln, preparing the kiln, loading of fuel and pots, and operating of the kiln-20 m-h; breaking the kiln, bringing pots inside the house and arranging them in order $-2 \mathrm{~m}-\mathrm{h}$ :

As the potter himself sells the pots to customers who come to his house there is no energy expenditure for transportation of the finished product. Table 3 gives the energy consumption for one pottery kilning.

\subsection{Blacksmithy and carpentry}

A combined wood- and metal-working shop turns out spades, bullock carts, axes, knives of different kinds, pickaxes, potter's wheels, etc. The shop possesses an anvil, a hand blower and a few sets of common smithy and carpentry tools.

4.3a Energy consumption of a smithy for an year: Three persons (sometimes an apprentice as well) work for $8 \mathrm{hr} /$ day. They work for 300 days/year. The fuel consumption per day is $50 \mathrm{~kg}$ of coal, $55 \mathrm{~kg}$ of rice husk and $30 \mathrm{~kg}$ of hay. One man usually travels to town ( $40 \mathrm{~km} /$ round trip) once a week to bring fuel, mild steel, scrap iron or some tool replacements.

The energy consumption is as follows: fuels-coal -15 tonnes $(t)$; rice husk $-16 \cdot 5 t$;

Table 3. Energy consumption per operation of a pottery kiln

\begin{tabular}{lcc}
\hline Energy & $\begin{array}{c}\text { Resource-end energy } \\
\left(\times 10^{3} \mathrm{kcal}\right)\end{array}$ & $\begin{array}{c}\text { End-point energy } \\
\left(\times 10^{3} \mathrm{kcal}\right)\end{array}$ \\
\hline Fuel & 983.2 & $88.9^{*}$ \\
$8 \mathrm{c}-\mathrm{h}$ & 99.1 & 4.9 \\
$82 \mathrm{~m}-\mathrm{h}$ & 188.1 & 5.6 \\
Total & 1270.4 & 99.4 \\
\hline
\end{tabular}

* Assuming a kiln efficiency of $9 \%$ 
hay-1 t; human energy for metal and wood working processes- $5500 \mathrm{~m}$-h; transportation to town-2000 m-km (man-kilometers); transportation of fuel and raw materials $-270 \mathrm{c}-\mathrm{h}$. Table 4 gives the energy consumption in a smithy.

4.3b Energy consumption for constructing a bullock cart: The energy consumption is as follows: Bending and softening of metal into two circular tyre shapes $-4 \mathrm{~m}-\mathrm{h}+400$ dung cakes; joining of the circular metal strips at the ends to form the tyre shapes$8 \mathrm{~m}-\mathrm{h}+4 \mathrm{~kg} \mathrm{coal}+5 \mathrm{~kg}$ rice husk; fabricating axle of cart $-8 \mathrm{~m}-\mathrm{h}+15 \mathrm{~kg}$ coal $+18 \mathrm{~kg}$ rice husk; fabricating 4 bearings of cart $-4 \mathrm{~m}-\mathrm{h}+4 \mathrm{~kg}$ coal $+5 \mathrm{~kg}$ rice husk; and carpentry part of the fabrication $-360 \mathrm{~m}-\mathrm{h}$. Table 5 gives the energy consumption for constructing a bullock cart.

4.4 Rice milling, flour milling, edible oil extraction by animal power and hand drilling of borewells

Table 6 gives the daily energy consumption for four rural industries both in natural units and energy units.

\subsection{Energy consumption and other data of some important rural devices}

Table 7 gives important information about some rural devices. This includes initial cost, expected life, time between repairs, time for construction and energy consumption for construction.

\subsection{Per capita industrial energy consumption}

To determine the per capita energy consumption, one has to identify a closed system where all production is internally consumed. With this aim, for every sample rural industry, the closed system is identified in terms of area covered, villages covered and population catered to. It can be assumed without serious error that the industrial

Table 4. Energy consumption in a smithy

\begin{tabular}{lcc}
\hline Energy & $\begin{array}{c}\text { Resource-end energy } \\
\left(\times 10^{3} \mathrm{kcal}\right)\end{array}$ & $\begin{array}{c}\text { End-point energy } \\
\left(\times 10^{3} \mathrm{kcal}\right)\end{array}$ \\
\hline Fuel & $229531 \cdot 5$ & $3443.0^{*}$ \\
$550 \mathrm{~m}-\mathrm{h}$ & 12613.0 & 378.4 \\
$2000 \mathrm{~m}-\mathrm{km}$ & 34.7 & 3.1 \\
Total & 242179.2 & 3824.5 \\
\hline
\end{tabular}

* Assuming a kiln efficiency of $1.5 \%$ for the blacksmith's furnace

Table 5. Energy consumption during construction of a bullock cart

\begin{tabular}{lcc}
\hline Energy & $\begin{array}{c}\text { Resource-end energy } \\
\left(\times 10^{3} \mathrm{kcal}\right)\end{array}$ & $\begin{array}{c}\text { End-point energy } \\
\left(\times 10^{3} \mathrm{kcal}\right)\end{array}$ \\
\hline Fuel & 641.0 & 9.6 \\
$384 \mathrm{~m}-\mathrm{h}$ & 880.6 & 26.4 \\
Total & 1521.6 & 36.0 \\
\hline
\end{tabular}


Table 6. Daily energy consumption for four rural industries

\begin{tabular}{|c|c|c|c|c|}
\hline Particulars & Rice mill & Flour mill & $\underset{\text { extractor }}{\text { Oil }}$ & $\begin{array}{c}\text { Borewell } \\
\text { digging }\end{array}$ \\
\hline $\begin{array}{l}\text { Main energy source } \\
\text { Energy consumption/ } \\
\text { for full processing }\end{array}$ & electricity & electricity & bullock & $\operatorname{man}$ \\
\hline i) $m-h$ & 56 & 16 & 8 & 32 \\
\hline ii) $b-h$ & - & - & 4 & - \\
\hline iii) $c-h$ & 136 & 4 & - & 2 \\
\hline iv) e-h & $126^{\circ}$ & $14^{b, c}$ & - & - \\
\hline $\begin{array}{l}\text { Volume of products } \\
\text { processed per day } \\
\left(\times 10^{2} \mathrm{~kg}\right)\end{array}$ & $\begin{array}{l}248- \\
\text { paddy }\end{array}$ & $\begin{array}{l}8.5- \\
\text { grain }\end{array}$ & $\begin{array}{c}0.5 \\
\text { groundnut/ } \\
\text { copra }\end{array}$ & $-d$ \\
\hline $\begin{array}{l}\text { Resource end energy } \\
\text { per day } \\
\quad\left(\times 10^{3} \mathrm{kcal}\right)\end{array}$ & 1952.3 & 216.81 & $43 \cdot 2$ & $98 \cdot 4$ \\
\hline $\begin{array}{l}\text { End point energy/ } \\
\left(\times 10^{3} \mathrm{kcal}\right)\end{array}$ & $585 \cdot 23$ & $60-68$ & 1.8 & 3.45 \\
\hline
\end{tabular}

- Total shaft HP of main drive + de-stoner + filler is $45 \mathrm{HP}(33.57 \mathrm{~kW})$ the overall system efficiency is $32 \%$;

b total shaft HP of main drive is 5 HP $(3.73 \mathrm{~kW})$, the overall system efficiency is $28 \%$; ' intermittent operation depending on customer load, the loads are small and vary between $1-25 \mathrm{~kg}$ for $80 \%$ of the time; d wells are struck in the summer months, the equipment is hired to users by its owner-it is not a skilled job and the water table $(8.5-9 \mathrm{~m}$ depth) can be reached within a day.

demand does not arise from outside this because every region has its own industry. When there is a nearby pottery, rice mill or blacksmithy, the villagers will not go out several miles for a similar facility. In most cases, the rural folk have fixed payments in kind for these facilities. If they go out they have to pay cash. Cash transactions exist but are kept to a minimum. Table 8 gives the data about two samples of each rural industry and table 9 gives the per capita energy consumption, the average of the two samples.

\section{Domestic energy consumption}

As already mentioned, this is estimated from two sources: individual family data and village level survey for four villages. Four villages were studied in detail to find out the energy consumption. Table 10 gives details about land and energy devices in these villages. It also determines the per capita energy consumption for these two sectors. domestic energy for six different households.

\section{Discussions and conclusions}

6.1 The paper evaluates industrial and domestic energy consumption in Nellore villages. It also determines the per capita energy consumption for these two sectors.

The different energies determined are:

(i) Taskwise energy consumption: The resource-end energy consumption and the corresponding end-point energy (within brackets) are as follows $\left(\times 10^{3} \mathrm{kcal}\right)$ 
Table 7. Information about some important rural devices

\begin{tabular}{|c|c|c|c|c|c|c|}
\hline \multirow[b]{2}{*}{ Equipment } & \multirow[b]{2}{*}{$\begin{array}{c}\text { Cost* } \\
\text { (Rs) }\end{array}$} & \multirow{2}{*}{$\begin{array}{l}\text { Total } \\
\text { life } \\
\text { (yr) }\end{array}$} & \multirow{2}{*}{$\begin{array}{c}\text { Time } \\
\text { between } \\
\text { repairs } \dagger(y r)\end{array}$} & \multirow{2}{*}{$\begin{array}{l}\text { Time for } \\
\text { construction } \\
\text { (h) }\end{array}$} & \multicolumn{2}{|c|}{$\begin{array}{l}\text { Energy for construc- } \\
\text { ction }\left(\times 10^{3} \text { kcal }\right)\end{array}$} \\
\hline & & & & & $\begin{array}{l}\text { Resource-end } \\
\text { energy }\end{array}$ & $\begin{array}{c}\text { End-point } \\
\text { energy }\end{array}$ \\
\hline Plough & $\begin{array}{l}\text { M-30 } \\
\text { F-50 }\end{array}$ & 3 & 1 & 12 & 27.5 & 0.8 \\
\hline $\begin{array}{r}\text { Potter's } \\
\text { wheel }\end{array}$ & $\begin{array}{l}\text { M-15 } \\
\text { F-35 }\end{array}$ & 6 & 1 & 8 & 22.9 & 0.7 \\
\hline $\begin{array}{l}\text { Bullock } \\
\text { cart }\end{array}$ & $\begin{array}{l}\text { M-3000 } \\
\text { F-900 }\end{array}$ & 10 & 3 & 120 & 1939.5 & $42 \cdot 3$ \\
\hline Axe $(4 \mathrm{~kg})$ & $\begin{array}{l}\text { M-8 } \\
\text { F-7 }\end{array}$ & 3 & 1 & 3 & 6.9 & 0.2 \\
\hline $\begin{array}{l}\text { Brick } \\
\text { casting } \\
\text { machine }\end{array}$ & $\begin{array}{l}\text { M-5 } \\
\text { F-5 }\end{array}$ & 1 & 0.1 & 1 & $2 \cdot 3$ & 0.08 \\
\hline $\begin{array}{l}\text { Machine for } \\
\text { hand digging } \\
\text { of borewells }\end{array}$ & 3,000 & 15 & 3 & - & $\mathbf{P}^{* *}$ & - \\
\hline Tractor & 75,000 & 25 & 3 & - & $\mathrm{P}^{* *}$ & - \\
\hline $\begin{array}{l}\text { Rice milling } \\
\text { machine }\end{array}$ & 60,000 & 25 & 3 & - & $\mathrm{P} * *$ & - \\
\hline $\begin{array}{l}\text { Flour } \\
\text { milling } \\
\text { machine }\end{array}$ & 12,000 & 30 & 2 & - & $P^{* *}$ & - \\
\hline $\begin{array}{l}\text { Oil extracting } \\
\text { apparatrus }\end{array}$ & $\begin{array}{l}\text { M-200 } \\
\text { F-300 }\end{array}$ & 20 & 1 & 32 & $147 \cdot 2$ & $5 \cdot 2$ \\
\hline
\end{tabular}

* July 1981 price level index; ** purchased in the market; + time between repairs denotes major repairs costing nearly 0.1 of the total equipment cost; M: materials; F: fabrication

(a) commercial brick burning- $10^{5}$ bricks: $146835 \cdot 0$ (14140.0); (b) non-commercial brick burning - $25 \times 10^{3}$ bricks: 33160 (1020); (c) potteries - 200 medium sized pots1270.4 (99.4); (d) blacksmithy-one year- 242179.2 (3824.5); (e) hand-drilling of borewell-one attempt-98.4 (3.45); (f) rice mill-one day-1952.3 (585.2); (g) flour mill—one day-216.8 (60.7); (h) oil extraction by bullock power-one day-43.2 (1.8).

(ii) Specific energy consumption for various tasks at the resource-end is as follows ( $\times 10^{3} \mathrm{kcal}$ ) (a) to produce a pot of $0.6 \mathrm{~kg}-6.3$; (b) to produce a brick of $1.2 \mathrm{~kg}-1.47$; (c) to fully process $1 \mathrm{~kg}$ of paddy-0.078; (d) to grind one $\mathrm{kg}$ of wheat to flour -2.55 ;

(e) to extract oil from $1 \mathrm{~kg}$ of groundnuts- 0.86 .

(iii) The percentage of local (resource-end) energy used for the different tasks is: brickburning-98.8; potteries-100; smithy-62.8; rice milling-0.09; flour milling - 0.04, domestic -97.2 to 98.9 . The complementary percentage is the external energy. Local energies are also renewable energies.

(iv) Annual per capita fuel and electrical energy consumption at the different villages at the resource-end is $\left(\times 10^{3} \mathrm{kcal}\right)$ : industry (common) -669.4; domestic: $1-2411 \cdot 3 ; 2$ - 
Talle 8. Viliage industrial data

\begin{tabular}{|c|c|c|c|c|c|c|}
\hline Industry & $\begin{array}{c}\text { Time for } \\
\text { operation } \\
\text { (hr) }\end{array}$ & $\begin{array}{l}\text { Period of } \\
\text { operation }\end{array}$ & $\begin{array}{c}\text { Operation/ } \\
\text { year }\end{array}$ & $\begin{array}{c}\text { Area } \\
\text { covered } \\
\left(\mathbf{k m}^{2}\right)\end{array}$ & $\begin{array}{l}\text { Villages } \\
\text { covered }\end{array}$ & $\begin{array}{l}\text { Population } \\
\text { covered }\end{array}$ \\
\hline \multicolumn{7}{|l|}{ Potteries at } \\
\hline i) Balijapalyam & 6 & January-August & $10(12)$ & 9.0 & 15 & 3000 \\
\hline ii) Kummarimitta & 5 & January-August & $8(9.5)^{r}$ & $12 \cdot 25$ & 19 & 3610 \\
\hline $\begin{array}{l}\text { Commercial brick } \\
\text { burning at }\end{array}$ & & & & & & \\
\hline i) Muthukur & 600 & March-June & $3(6)^{*}$ & $25-0$ & 30 & 7500 \\
\hline ii) Epur & 525 & & $5(5)^{b}$ & $20-25$ & 25 & 5500 \\
\hline \multicolumn{7}{|l|}{$\begin{array}{l}\text { Blacksmithy at } \\
\text { i) Paturuvari }\end{array}$} \\
\hline Kandriga & 8 & 300 days & 300 & 40 & 8 & 2240 \\
\hline ii) Brahma devi & 8 & & 280 & $9 \cdot 0$ & 15 & 3140 \\
\hline \multicolumn{7}{|l|}{$\begin{array}{l}\text { Hand-drilling of } \\
\text { borewells at }\end{array}$} \\
\hline i) Pudiparthi & 8 & February-August & 55 & $5 \cdot 75$ & 8 & 1920 \\
\hline ii) Sarvepalle & 8 & & 48 & 6.5 & 11 & 2750 \\
\hline \multicolumn{7}{|l|}{ Rice mills at } \\
\hline i) Muthukur & 14 & Whole year & 330 & 160 & 20 & 10000 \\
\hline ii) Krishnapatnam & 12 & & 300 & 90 & 6 & 5000 \\
\hline Flour mills at & & Whole year & & & & \\
\hline i) Brahma devi & 15 & & 300 & $12 \cdot 5$ & 16 & 5600 \\
\hline ii) Kakupalle & 12 & & 275 & 7.0 & 11 & 3960 \\
\hline \multicolumn{7}{|l|}{ Oil extraction } \\
\hline apparatus at & & Whole year & & & & \\
\hline i) Muthukur (two units) & 4 & & 150 & 16.0 & 20 & 10000 \\
\hline ii) Gopalapuram & 4 & & 60 & 6.25 & 6 & 1500 \\
\hline \multicolumn{7}{|l|}{ Non-commercial brick } \\
\hline i) Varkavipudi & 300 & & $5(10)$ & - & 1 & 1000 \\
\hline ii) Chennur & 375 & & $2(4)^{x}$ & - & 1 & 325 \\
\hline
\end{tabular}

a Values in brackets show the number of operations equivalent in energy to the burning of 200 pots; Values in brackets show the number of operations equivalent in energy to the firing of $10^{5}$ bricks; "Values in the brackets show the number of operations equivalent in energy to the firing of $25 \times 10^{3}$ bricks.

$2054 \cdot 3 ; 3-2730 \cdot 8 ; 4-2627.9$. The percentage of fuel and electrical energy for the different sectors in these villages are: industry (common): 94.4 ; domestic: $1-43.5 ; 2$ $35 \cdot 8 ; 3-57 \cdot 1 ; 4-60 \cdot 5$. The complementary percentages denote the animal and human energy.

Overall efficiencies of the sectors in the villages are (total end-point energy/total resource-end energy) (\%): industry: 13.3 ; domestic: $1-4.2 ; 2-4.0 ; 3-4.6 ; 4-4.7$.

Firewood consumption for domestic tasks for the house to house (6 households) survey varied between 434 and $620 \mathrm{~kg} /$ year with a mean of $525 \mathrm{~kg} /$ year. In the village to village survey (4 villages) it varied between 475 and $621 \mathrm{~kg} /$ year with a mean of $556 \mathrm{~kg} /$ year. All these are per capita values.

In an urban firewood survey (Reddy \& Reddy 1983), the per capita firewood consumption varied between 330 and $396 \mathrm{~kg} /$ year for both cooking and water heating and between 167 and $202 \mathrm{~kg} /$ year for cooking alone. 
Table 9. Annual per-capita energy consumption for rural industries

\begin{tabular}{|c|c|c|c|c|}
\hline \multirow[b]{2}{*}{ Industry } & \multicolumn{2}{|c|}{ Total energy/village (Av) } & \multicolumn{2}{|c|}{ Per-capita energy (Av) } \\
\hline & Resource-End & End-point & Resource-end & End-point \\
\hline Potteries & $27,313 \cdot 6$ & $2,130 \cdot 5$ & $4 \cdot 1$ & 0.3 \\
\hline \multicolumn{5}{|l|}{ Brick burning } \\
\hline i) Commercial & $1,615,185$ & $155,057 \cdot 8$ & $125 \cdot 2$ & 11.9 \\
\hline ii) Non-commercial & 232,120 & 7,140 & $369 \cdot 8$ & $11 \cdot 3$ \\
\hline Blacksmithy & $484,358 \cdot 4$ & $7,749 \cdot 0$ & 900 & 1.4 \\
\hline Hand-boring of wells & $10,124 \cdot 9$ & $335 \cdot 5$ & $2 \cdot 2$ & $\mathbf{N}$ \\
\hline Rice mill & $614,974 \cdot 5$ & 184,338 & 90.7 & $27 \cdot 2$ \\
\hline Flour mill & 62,330 & $17,451 \cdot 2$ & 26.6 & $7 \cdot 4$ \\
\hline \multicolumn{5}{|l|}{ Oil extraction } \\
\hline equipment & 4,536 & 189 & $1 \cdot 2$ & $\mathbf{N}$ \\
\hline Total & $2.820 \times 10^{6}$ & $0.374 \times 10^{6}$ & 708.8 & 59.5 \\
\hline
\end{tabular}

All energy values in $10^{3} \mathrm{kcal} ; \mathrm{N}$-negligible; $\mathrm{Av}$-average

Table 10. Basic data about four Nellore villages

\begin{tabular}{|c|c|c|c|c|}
\hline \multirow[b]{2}{*}{ Details } & \multicolumn{2}{|c|}{ Village } & \multirow[b]{2}{*}{3} & \multirow[b]{2}{*}{4} \\
\hline & 1 & 2 & & \\
\hline Village name & $\begin{array}{l}\text { Paturuvari } \\
\text { kandriga }\end{array}$ & Mamidipudi & Mollur & Kummarimitta \\
\hline Population & 339 & 418 & 207 & 172 \\
\hline Land" & $\begin{array}{r}110-W \\
58-D\end{array}$ & $\begin{array}{r}260-W \\
83-D\end{array}$ & $\begin{array}{r}\text { 35-W } \\
\text { 8-D }\end{array}$ & $\begin{array}{r}38-W \\
24-D\end{array}$ \\
\hline $\begin{array}{l}\text { Number of } \\
\text { houses }\end{array}$ & 76 & 86 & 42 & 33 \\
\hline Pumpsets $^{b}$ & $\begin{array}{r}32-E \\
6-D\end{array}$ & $\begin{array}{r}46-E \\
8-D\end{array}$ & $5-E$ & $\begin{array}{r}11-E \\
2-D\end{array}$ \\
\hline Bullock carts ${ }^{c}$ & $\begin{array}{r}27-T \\
5-H\end{array}$ & $\begin{array}{r}40-T \\
5-H\end{array}$ & $5-T$ & $4-T$ \\
\hline Other vehicles & - & $\begin{array}{l}4-\mathrm{Tr} \\
2-\mathrm{C} \\
2-\mathrm{M}\end{array}$ & - & $1-M$ \\
\hline Cattle & 348 & 454 & 237 & 192 \\
\hline Electric loads ${ }^{e}$ & $\begin{array}{r}50-\mathrm{L} \\
8-\mathrm{F}\end{array}$ & $\begin{array}{r}184-\mathrm{L}, \\
22-\mathrm{F}\end{array}$ & $\begin{array}{l}\text { 15-L, } \\
\text { 1-F }\end{array}$ & $\begin{array}{l}13-L \\
2-F\end{array}$ \\
\hline Kerosene lamps ${ }^{f}$ & $\begin{array}{l}78-B \\
87-S\end{array}$ & $\begin{array}{l}79-B \\
80-S\end{array}$ & $\begin{array}{l}56-B \\
47-S\end{array}$ & $\begin{array}{l}41-B \\
52-S\end{array}$ \\
\hline
\end{tabular}

a W-wet land, D-dry land (hectares); ' E-electric, D-diesel; ' T-load transport, H-Human travel; ' Tr-tractor, C-car, M-motorbicycle; - $40 \mathrm{~W}$ lamp or equivalent-L, F-fan; $f \mathrm{~S}-$ small lamp, B-big lantern

The rural consumption thus is nearly three times that of the urban consumption. This could be because of the following factors:

(i) In urban areas firewood is a commercial fuel and costs about Rs $0.55 / \mathrm{kg}$ whereas in Nellore villages it is a non-commercial fuel. There is not a single household which buys firewood in these regions. 
Table 11. Domestic energy for the four villages, each being considered as a unit

\begin{tabular}{|c|c|c|c|c|}
\hline Particulars & 1 & 2 & 3 & 4 \\
\hline \multicolumn{5}{|l|}{ Energy of firewood for } \\
\hline domestic tasks/day & $2135 \cdot 7$ & $2282 \cdot 3$ & $1478 \cdot 0$ & $1192 \cdot 0$ \\
\hline Domestic electricitye, ber day & $15 \cdot 5$ & $24 \cdot 8$ & 6.0 & $5 \cdot 16$ \\
\hline Kerosene/day & 83.9 & $38 \cdot 15$ & $61 \cdot 0$ & $39 \cdot 0$ \\
\hline Travel to town/day & $4 \cdot 41$ & $7 \cdot 36$ & 3.68 & $2 \cdot 21$ \\
\hline \multicolumn{5}{|l|}{ Human energy for domestic } \\
\hline tasks/day & $1858 \cdot 4$ & $2806 \cdot 0$ & 662.4 & 395.6 \\
\hline Energy for maintaining cattle/day & $1048 \cdot 8$ & 1407.6 & $469 \cdot 8$ & 4140 \\
\hline Per-capita' energy/day & $15 \cdot 2$ & $15 \cdot 7$ & $13 \cdot 1$ & 11.9 \\
\hline Per-capita end-point energy/day & 0.64 & 0.63 & 0.60 & 0.56 \\
\hline Per-capita energy/year & 5548 & 5730.5 & $4781 \cdot 5$ & $4343 \cdot 5$ \\
\hline Per-capita end-point energy/year & 233.6 & 229.9 & 219 & $204 \cdot 4$ \\
\hline
\end{tabular}

All values are $\times 10^{3} \mathrm{kcal} ; \quad{ }^{a}$ includes home lighting, fans and street lights; ${ }^{b}$ estimated from table 10 ; c populations got from table 10. Energies are resource-end energies, except where otherwise stated

Table 12. Domestic energy for six different households

\begin{tabular}{|c|c|c|c|c|c|c|}
\hline Particulars & 1 & 2 & 3 & 4 & 5 & 6 \\
\hline Family size & 5 & 7 & 6 & 4 & 5 & 3 \\
\hline No of persons for whom food is cooked ${ }^{*}$ & 8 & 9 & 10 & 5 & 5 & 4 \\
\hline Firewood"/day (kg) & $9 \cdot 5$ & $13 \cdot 5$ & 17.0 & 6.0 & 7.5 & 6.0 \\
\hline Electricity/month (kWh) & $26 \cdot 0$ & $20 \cdot 0$ & $27 \cdot 5$ & $8 \cdot 0$ & - & - \\
\hline Kerosene/month (litres) & - & - & - & - & 40 & 3.0 \\
\hline Travel to town/yr (man-km) & 1276 & 1892 & 2386 & 1792 & 464 & 1820 \\
\hline $\begin{array}{l}\text { Human energy for domestic tasks/day } \\
(m-h)\end{array}$ & $23 \cdot 5$ & $24-75$ & $31 \cdot 0$ & $19 \cdot 5$ & 14.0 & $18 \cdot 5$ \\
\hline $\begin{array}{l}\text { Energy for maintaing cattle/day }(m-h) \\
\text { Per capita resource-end energy/day }\end{array}$ & $1 \cdot 2$ & 0.65 & 0.78 & $4 \cdot 0$ & 10 & $2 \cdot 75$ \\
\hline $\begin{array}{l}\left.\text { ( } \times 10^{3} \mathrm{kcal}\right) \\
\text { Per capita end-point energy/day }\end{array}$ & $19 \cdot 5$ & $16 \cdot 5$ & $24 \cdot 2$ & $19 \cdot 9$ & $13 \cdot 5$ & $25 \cdot 3$ \\
\hline$\left(\times 10^{3} \mathrm{kcal}\right)$ & 0.8 & 0.7 & $1 \cdot 1$ & 0.8 & $0-6$ & 1.0 \\
\hline $\begin{array}{l}\text { Per capita resource-end energy/year } \\
\left(\times 10^{3} \text { kcal }\right)\end{array}$ & $7117 \cdot 5$ & $6022 \cdot 5$ & 8833 & 7263.5 & 4927.5 & 9234.5 \\
\hline $\begin{array}{l}\text { Per capita end-point energy/year } \\
\left(\times 10^{3} \mathrm{kcal}\right)\end{array}$ & 292 & 255.5 & 401.5 & 292 & 219 & 365 \\
\hline
\end{tabular}

- This may include some farm or domestic help who don't stay in the same house - Prosopis julifiora (Calorific value $\approx 4200 \mathrm{kcal} / \mathrm{kg}$ ); (Total animals/total time)

(ii) Prosopis julifiora, a fast growing, self-spreading tree was planted in Nellore villages about sixty years back to prevent desertification. Whenever it is cut this tree regenerates naturally and produces about 100 to $150 \mathrm{~kg}$ wood/tree once every three years. Old people still remember a severe firewood crisis before the advent of this "wonder shrub". Now there is no firewood shortage in this locality, which of course, might have resulted in excessive consumption.

(iii) Urban stoves are more efficient than rural ones. The stove combustion chamber height, which mainly determines how much heat reaches the pot, is smaller in urban 
stoves. It is about 10 to $12 \mathrm{~cm}$ in urban stoves and about $15 \mathrm{~cm}$ in rural stoves. To give a higher heat output, the people in villages use excess fuel.

\subsection{Possibilities of technology transfer}

There is ample scope for exchange of technology between Nellore and other areas. For instance, the rice-husk-fired brick burning technique of Nellore is unknown in surplus rice husk regions like the Uttara Kannada district (Karnataka State). Actually, the people of the above region are desperate for some such technology. Firing potter's kilns by rice husk, a well known technique in the Bangalore district (Karnataka State), is not known to the Nellore potters. Bullock carts of the Nellore district are inferior to those of the Dakshina Kannada district of Karnataka. Thus, there are many such instances where technology transfer between different regions is possible.

\subsection{Improved devices}

It is possible to improve the efficiency and performance of present techniques in many cases by suitable redesigning of existing devices and incorporating minor changes in the procedure adopted, for example-

(i) scientifically designing the blacksmith's furnace with hand adjustable control of rice husk feed, coal feed and air flow; and prevention of radiation losses

(ii) introducing simple air and fuel controls to the potters' kiln

(iii) direct coupling to prevent frequent breakdowns and also reduce slippage losses, thus eliminating belting problems in rice mills.

The author wishes to thank the referee for the excellent review which has resulted in the rewriting of this paper in its present form. He also wishes to thank Prof. Roddam Narasimha for valuable suggestions.

\section{References}

Birch DR, Rudzewski J 1980 Energy options for low lift irrigation pumps in developing countries: The case of Bangladesh and Esypt, wEP 2-22/wP 57, Geneva, (L.L.O)

Forbes R J 1958 A history of technology (ed.) Charles Singer et al (London: Oxford University Press) Vol. 4

Hogg W H 1971 Potential crop production (ed.) P T Wareing. J P Cooper (London: Heinemann)

Makhijani A 1977 Economic and Political Weekly 12: 1452-64

Mani A 1981 Handbook of solar radiation data for India (New Delhi: Allied Publishers)

Pierce J R 1975 Sci. Am. 232(1): 34-44

Reddy A K N, Reddy B S 1983 Economic and Political Weekly 18: 1757-70

Revelle R 1976 Science 194: 969-75

Wilson S S 1977 Pedal power (ed.) J C McCullagh (UK: Rondale Press)

Wise D L 1981 Solar energy 26: 455-57 